\title{
Job satisfaction and basic vital needs satisfaction among working women
}

\author{
I. Kalva and D. Shiryayev \\ Baltic International Academy, Riga, Latvia
}

\begin{abstract}
Due to the achieved formal gender equality, traditional social roles within families have changed - approximately a half of women do not only raise children and run their households, but are working in some profession also. However, women feel themselves more responsible for family issues in comparison with their husbands, and that makes them sacrifice professional and career interests for the sake of family and children.

The aim of the research is to investigate the level of job satisfaction and its relation with satisfaction of basic vital needs (according to Maslow's needs pyramid) in working women - single and married.

A positive correlation was found between the level of job satisfaction and the level of satisfied material needs and security needs in working women. Some differences were found between single and married working women in levels of job satisfaction: $31 \%$ of single working women were satisfied fully by their job (but only $4 \%$ of the married). It was shown that the need for communication is correlated neither with job satisfaction nor with civil status of women. The need for recognition was partially satisfied in both women's groups, even in the case of their satisfaction with job. In case of dissatisfaction with job both groups demonstrated dissatisfied need for recognition. The need for self-expression was satisfied partially or dissatisfied in both groups of working women.

Generally, all basic vital needs were satisfied on the lower level among married women. So, a presence of work-life imbalance indirectly has been shown in the married women, who have to sacrifice a better paid job for the sake of having more free time for the family. Such rejection of some social roles in working women (moms) has been reported in literature.
\end{abstract}

Key words: job satisfaction, basic vital needs' satisfaction, working women, work-life balance

\section{Introduction}

The work-family conflict, work-life balance, satisfaction with the life and subjective wellbeing have become favourite topics for sociologists and social psychologists. Life satisfaction is considered as a part of broader concept of subjective well-being, which in turn is determined as a broad category of phenomena expressing itself in emotional reactions of people, their satisfaction with individual areas of life, as well as their opinions about the quality of life in whole. The most significant factors affecting satisfaction with life as a whole is financial status and subjective health assessment [1].

Many investigators have recently turned to the problem of work-life balance. There have been several investigations into differences of life satisfaction and work-life balance among men and women, representatives of different professions. Strong imbalance in the personal and work life is felt by representatives of raw materials' extraction sphere, virtually every 
second employee of the industry faces with similar problems. On the contrary, the most harmonious in this respect looks professional area of sports and fitness [2].

Both female and male surgeons worked long hours, both felt satisfied or very satisfied with their current job situation and were happy or very happy with other aspects of their lives. Both female and male surgeons faced many difficulties in their working lives; women may have more difficulties regarding family issues, more female surgeons remained single and more married female surgeons had no children [3].

There was a significant difference between job and life satisfaction levels of the academicians depending on the variables like the faculties that academic personnel work at, their titles, educational backgrounds, marital status, length of duty, ages and genders [4]. The employees explained the imbalance between work and personal life with conditions (32\%); they blamed themselves (31\%) or the employer (33\%) [2].

Gender equality among men and women exists formally and traditional social roles within families have changed. Women do not only raise children and run their households, but also have a professional job. Sometimes men substitute women for their role at home. Regardless of the fact that men spend more time on cleaning and child care, women still feel the emotional responsibility for home and family [5]. Differences continue to exist in the household tasks and parental roles of men and women [6].

A solid majority of Americans reject the idea that women should return to their traditional roles in society, and most believe that both husband and wife should contribute to the family income. But in spite of these long-term changes in behaviours and attitudes, many women remain conflicted about the competing roles they play at work and at home. Working mothers in particular are ambivalent about whether full-time work is the best thing for them [7].

A growing number of women start their own business in order to combine paid work and family life. Autonomy appeared to be an important resource, allowing them to combine their work more easily with childcare, household duties, and social and personal life [8].

However, women feel themselves more responsible for family issues, in comparison with their husbands, making them sacrifice professional and career interests for the sake of family and children.

There are incomplete evidences of relationship between job satisfaction and life satisfaction in working men and women. There are no doubts that these variables are linked. But it is not clearly shown whether there is any causal relation. Some statements, such as that work-life balance is the key to job satisfaction [9], only support our interest in this problem. We could not find convincing studies on basic vital needs' satisfaction and its impact on life satisfaction among working married women.

The purpose of the present research is: to investigate the level of job satisfaction and its relation with satisfaction of basic vital needs in working women - single and married.

\section{Methodology of research}

We used two psychological tests: the test of satisfaction with job and the test of basic vital needs' satisfaction.

1. "The test of satisfaction by job" (the author V.A.Rozanova) [10].

The test contains 14 statements about different aspects of work. Each statement can be estimated from 1 to 5 points. Evaluation is made on the following scale:

15-20 very satisfied

21-32 satisfied

33-44 not completely satisfied

45-60 dissatisfied

Over 60 marginally dissatisfied 



Figure 1. Job satisfaction. The left - single women; the right - married women. 1 - percentage of women satisfied by job; 2 - percentage of women dissatisfied by job.

2. "The test of basic vital needs' satisfaction" (the author V.V. Skvortsov, in modification of I.A. Akindinova) [11].

This technique allows identifying the basic needs - motivators of individuals and groups. Its basis is the procedure for pair comparisons. The theoretical basis of the test was the modified Maslow's pyramid of needs. Instead of physiological needs, lying in the bottom of the pyramid of needs, Skvortsov introduced needs in material maintenance of life. The test reveals relative satisfaction, that is, satisfaction of the needs compared with other needs. As a result, the test subject gets a list of motivating him (her) current needs (unmet needs), and a list of satisfied and partially satisfied needs that do not currently play a crucial role in the activity of the individual.

Instructions. In front of you are 15 statements that you must evaluate in pairs, comparing them with each other. During the work it is beneficial to every statement pronounce the phrase: "I want ...". When you have finished, count the number of points (elections), dropped out on each statement.

Select 5 statements that have received the most points, and place them in the hierarchy. It is your basic needs.

Selection - 87 women working in different enterprises and organizations in Riga (Latvia). Among them 39 single, 48 - married (including partner relations). Median age - 37. Number of children was not analysed. All women were given two questionnaires and asked to fill out after having previous explanation.

Each questionnaire was processed manually.

Standard statistical methods were used for data analysis: EXCEL (means, standard deviations, and graphs). SPSS 18 was used for correlation analysis (Pearson), and WicocsonMann-Whitney U-criteria calculations.

\section{Results of research}

\section{Job satisfaction}

According to the applied method, it is possible to define 4 levels of job satisfaction: very satisfied, satisfied, not completely satisfied, and dissatisfied. Results demonstrated higher level of job satisfaction among single working women, in comparison with married working women, what was reflected in both distribution and in general average level of satisfaction.

This diagram (Fig. 1) shows that $90 \%$ of single working women are satisfied with job (put together very satisfied and satisfied), but only $27 \%$ of married working women, accordingly, 


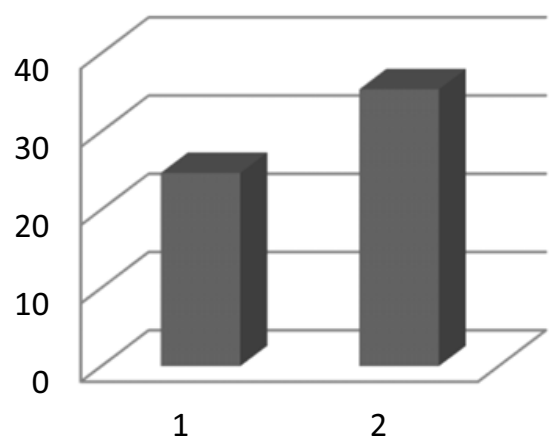

Figure 2. The level of job satisfaction. The left - single women; the right - married women. (Job satisfaction is higher, if mean was lower $)(\mathrm{P}<0.001$; U-criteria. $)$

Table 1. Pearson's correlations between Job satisfaction and basic needs' satisfaction in married working women (Here, minus does not mean negative correlation, because of inverse values for job satisfaction); *significance $\mathrm{P}<0.05$.

\begin{tabular}{|c|c|c|c|}
\hline Material needs & Security needs & Social needs & Recognition needs \\
\hline,$- 309^{*}$ &,$- 347^{*}$ &,$- 350^{*}$ &,- 213 \\
\hline
\end{tabular}

are satisfied with job (put together very satisfied and satisfied). As the diagram shows, $10 \%$ of single working women are not satisfied with job (10\% are not completely satisfied, and $0 \%$ - dissatisfied), but among working married women this percentage is higher - 73\% (58\% are not completely satisfied, $15 \%$ totally dissatisfied).

\section{Satisfaction of basic vital needs}

As it was designed in the applied method, 5 basic needs were defined: material needs, security needs, social needs, recognition needs, and self-expression needs. Each of needs was divided into three levels: satisfied, partially satisfied, and dissatisfied need. It was revealed that single working women had more satisfaction of all basic vital needs, comparing with married working women. Significant differences appeared between single and married women in the case of their satisfaction with job: $31 \%$ of single working women (satisfied with job) evaluated their material and security needs as satisfied. Only $4 \%$ of married working women (satisfied with job) evaluated their material and security needs as satisfied ( $\mathrm{p}<0,05$; U-criteria).

Among married working women $73 \%$ had incompletely satisfied material needs $(58 \%)$ and unsatisfied material needs $(15 \%)$. These $73 \%$ of women also evaluated as dissatisfied their security needs, recognition needs, and needs in self-expression.

\section{Correlations between job satisfaction and basic material needs}

Positive correlations were found between job satisfaction and satisfaction of basic vital needs in both examined groups of women. Job satisfaction positively correlated with satisfaction of material needs, security, and social needs among married working women (Table 1).

Job satisfaction positively correlates with satisfaction of material needs and recognition needs among single working women (Table 2). 
Table 2. Pearson's correlation between Job satisfaction and basic needs' satisfaction among single working women. (Here, minus does not mean negative correlation, because of inverse values for job satisfaction); *significance $\mathrm{P}<0.05$.

\begin{tabular}{|c|c|c|c|}
\hline Material needs & Security needs & Social needs & Recognition needs \\
\hline,$- 407^{*}$ &,- 133 &,- 273 &,$- 346^{*}$ \\
\hline
\end{tabular}

\section{Discussion}

Results confirmed a hypothesis about difference between working single women and working married women in levels of job satisfaction and levels of basic vital needs' satisfaction: the level of job satisfaction among single working women was significantly higher than among married working women. Regardless of correlations revealed between job satisfaction and satisfaction of basic vital needs in both groups, differences between two examined groups in the levels of basic vital needs' satisfaction were found only among women, satisfied by job: most (over 50\%) of single working women had satisfied their material needs, minority (10\%) of married working women had satisfied their material needs. Among single working women, nearly $50 \%$ have satisfied their security needs, and $8 \%$ - among the married ones. "Needs in security" means that the person feels good about chances for future, some sustainability, and possibility to avoid troubles. We cannot define reasons of the established facts in this study. In our opinion, single working women may do more paid job, comparing to married working women, or they can work longer hours, they can feel more safely position in organization they work. We imply that lower levels of job satisfaction and basic vital needs' satisfaction in married working women impact their sense of well-being, and reflect work-family conflict. In this context, our findings have a support in literature sources: work-family conflict has a significant negative relationship with life satisfaction and job satisfaction (Naz, Samina, Gul, Seema, Haq, Anisul, 2011) [12].

Another regularity that was disclosed among married working women: job satisfaction positively correlated not only with satisfaction of material needs and security, but also with social needs. This means that person wants to have warm relations, to communicate and be understood by others. So, married women maybe need job as a place for communication (other as at home). Stevenson, Wolfers (2009) [13] found that the correlation between happiness and marital happiness is lower for women who work compared with housewives.

Job satisfaction positively correlates with satisfaction of material needs and recognition needs among single working women. The need in recognition means that a person strives to get recognition as a professional, to increase skills and competence, to provide some status. Our results showed that single working women are able to satisfy these needs. We suppose that single working women may have higher positions than the married, generally. Probably, married women need to choose lower positions, but more suitable for family life.

All differences described above may also indicate that married women are not satisfied with job and with basic vital needs because they do not work full-time job, but parttime. In many cases women choose part-time job to avoid the conflict between work and family. According to Roeters and Craig (2014) [14], part-time work reduces worklife conflict to a similar extent in many countries. A strong majority of all working mothers $(62 \%)$ say they would prefer to work part-time. Only $37 \%$ of working mothers would prefer to work full time. (The Harried Life of the Working Mother. October 1, 2009. http://www . pewsocialtrends . org/2009/10/01/the-harried-life-of-theworking-mother) [7].

It was marked, that women themselves organize needed balance between two important aspects of their life. Thus, in recent years, has appeared such phenomenon as "deferred motherhood" - women delay having children at a later date in order to gain professional 
experience, to gain a foothold in the labour market and to have an easier way "Back to the profession" after childbirth (Савинская, 2013) [15]. Such "self-regulation" way of work/life balance leads to bad demography: more women surgeons remained single and more married women surgeons had no children in Hong Kong (Sharon Wing-Wai Chan, Polly Suk-Yee Cheung, Janet Fung-Yee Lee, James Tak-Kwan Fung, Patil, Nivritti G., Samuel, 2010) [3].

Additionally, women have found one more way of reducing work-life conflict: shift working. Nurses working morning shifts only experienced less conflict between work and family than other groups of nurses, who worked the morning, afternoon, and the night shift. Šimunić, Ana, Gregov, Ljiljana (2012) [16].

So, married working women indirectly were shown in our study to experience a worklife imbalance: they agree to work less paid jobs, feel less security, be unrecognized and not self-expressed, but have more free time for the family, for social needs, for house works and children. Satisfaction of basic vital needs and job satisfaction may serve as indicators of life satisfaction.

\section{Conclusions}

1. The level of job satisfaction among single working women is significantly higher, than among married working women. Job satisfaction positively correlates with satisfaction of material needs in both groups.

2. Job satisfaction positively correlates with satisfaction of material needs, security, and social needs among married working women. $\mathrm{P}<0.05$ (Pearson's $\mathrm{r}$ ).

3. Job satisfaction positively correlates with satisfaction of material needs and recognition needs among single working women. $\mathrm{P}<0.05$ (Pearson's $\mathrm{r}$ ).

4. There is a difference in the level of basic vital needs' satisfaction between single and married working women, satisfied by job: above $50 \%$ of single working women have satisfied their material needs, and $10 \%$ - among married. $\mathrm{P}<0.05$; U-criteria; among single working women nearly $50 \%$ have satisfied their security needs, and $8 \%$ - among married. $\mathrm{P}<0.05$; U-criteria.

5. Satisfaction of needs in communication among married working women positively correlated with satisfaction with job. $\mathrm{P}<0.05$ (Pearson's r).

6. The need in recognition among single working women is more satisfied, only in the case of satisfaction with job. $\mathrm{P}<0.05$; U-criteria.

7. The need in self-expression among single working women correlates positively strongly with job satisfaction. The need of self-expression is more satisfied in single women. $\mathrm{P}<0.05$ (Pearson's r).

8. Married women's basic needs are satisfied at lower level, regardless of having a husband (partner).

\section{References}

[1] Андреенкова Н.В., Сравнительный анализ удовлетворенности жизнью и определяющих ее факторов. Мониторинг общественного мнения N5 (99) Сентябрь-Октябрь (2010) http://cyberleninka.ru/article/n/ sravnitelnyy-analiz-udovletvorennosti-zhiznyu-i-opredelyayuschihee-faktorov

[2] Как достичь баданса между работой и жизнью Блог компании. SmartProgress, GTD 10.07.2013 11:56 http://habrahabr.ru/company/ smartprogress/blog/196220/ 
[3] Sharon Wing-Wai Chan, Polly Suk-Yee Cheung, Janet Fung-Yee Lee, James TakKwan Fung, Patil, Nivritti G., Samuel Po-Yin Kwok, Siu-Ho Lam, Women surgeons in Hong Kong. Surgical Practice 14(2010) http: //web.b. ebscohost. com/ehost/ detail/detail?vid=49\&sid=8b212ea7-946d-40cf $-9735-c 74750 a 07 f f 5 \% 40$ sessionmgr112\&hid=116\&bdata= Jmxhbmc9cnUmc210ZT1laG9zdC1saXZl\#db= a9h\&AN $=47716138$

[4] Filiz, Zeynep, An Analysis of the Levels of Job Satisfaction and Life Satisfaction of the Academic Staff. Social Indicators Research 116 (2014).

[5] Левянт Ю., Феминизм зебрал у женщин личное счастье. Электронное периодическое издание 5. «Информационне» агенство «Финмаркет» 03.08. 2014 11:24 http://www.finmarket.ru/archive/?srch=\&sec=0\&df= $01.03 .2014 \& d t=08.03 .2014 \& x=44 \& y=12$

[6] Maintier, Christine, Joulain, Michèle, Le Floc'h, Nadine, To what extent do attitudes to work and the subjective components of non-work contribute to the life satisfaction of men and women in dual-earner couples? Women's Studies International Forum 34 (2011) http://web.b.ebscohost.com/ehost/detail/detail?vid=45\&sid= 8b212ea7-946d-40cf-9735-c74750a07ff5\%40sessionmgr112\&hid=116\& bdata $=$ Jmxhbmc9cnUmc210ZT1laG9zdC1 saXZl\#db=a9h\&AN=71426920

[7] The Harried Life of the Working Mother. 10.01.2009 http://www . pewsocialtrends .org/2009/10/01/the-harried-life-of-the-workingmother

[8] Annink, Anne den Dulk, Laura, Autonomy: the panacea for self-employed women's work-life balance? Community, Work \& Family 15(2012) http://web.b. ebscohost. com/ehost/detail/detail?vid=40\&sid=8b212ea7-946d-40cf 9735-c74750a07ff5\%40sessionmgr112\&hid=116\&bdata=Jmxhbmc9cnUmc210 ZT1laG9zdC1saXZ1\#db=a9h\&AN=82969114

[9] Nelson, Rick, Work/Life Balance Key to Job Satisfaction. EE: Evaluation Engineering 52 (2013).

[10] Розанова, В. А., Психология управления : учеб. пособие (М., Альфа-Пресс, 2008).

[11] Райгородский Д.Я., Практическая психодиагностика. Методики и тесты: Учебное пособие (Самара, ИДБАХРАХ, 1998).

[12] Naz, Samina, Gul, Seema, Haq, Anisul, Relationship of Work-Family Conflict with Job Satisfaction and Life Satisfaction in High Tech Industrial Employees. International Journal of Academic Research 3 (2011) http://web.b.ebscohost.com/ehost/ detail/detail?vid=10\&sid=8b212ea7-946d-40cf-9735-c74750a07ff $5 \% 40$ sessionmgr112\&hid=116\&bdata=Jmxhbmc9cnUmc210ZT1laG9zdC1saXZl\#db= a9h\&AN=80232549

[13] Stevenson, Betsey, Wolfers, Justin, The Paradox of Declining Female Happiness. American Economic Journal: Economic Policy 1:2 (2009) http://www.aeaweb. org/articles.php?doi=10.1257/pol.1.2.190.

[14] Roeters, Anne, Craig, Lyn, Part-time work, women's work-life conflict, and job satisfaction: A cross-national comparison of Australia, the Netherlands, Germany, Sweden, and the United Kingdom. International Journal of Comparative Sociology (Sage Publications, Ltd.) 55(2014) http://web.b.ebscohost.com/ehost/ detail/detail?vid=9\&sid=8b212ea7-946d-40cf $-9735-c 74750 a 07 f f 5 \% 40$ sessionmgr112\&hid=116\&bdata=Jmxhbmc9cnUmc210ZT1laG9zdC1saXZl\#db= a9h\&AN $=98360651$ 
[15] Савинская О.Б., Баланс работы и семьи: стратегии совмещения профессиональных и семейных обязанностей работающими матерями в Москве (2013) http://jourssa.ru/sites/all/files/volumes/2013_2/ Savinskaya_2013_2.pdf

[16] Šimunić, Ana, Gregov, Ljiljana, Conflict Between Work and Family Roles and Satisfaction Among Nurses in Different Shift Systems in Croatia: a Questionnaire Survey.Archives of Industrial Hygiene \& Toxicology / Arhiv za Higijenu Rada I Toksikologiju 63 (2012). 